\title{
Effects of plant cover on properties of rhizosphere and inter-plant soil in a semiarid valley, SW China
}

\author{
Laiye $Q u^{\text {a, } 1}$, Yuanyuan Huang a, b, 1 , Keming Ma ${ }^{\text {a, }{ }^{*}}$, Yuxin Zhang ${ }^{a}$, Arjen Biere ${ }^{c}$ \\ a State Key Laboratory of Urban and Regional Ecology, Research Center for Eco-Environmental Science, Chinese Academy of Sciences, Beijing 100085, China \\ ${ }^{\mathrm{b}}$ Soil and Water Science Department, University of Florida, P.O. Box 110510 Gainesville, FL 32611, USA \\ ${ }^{\mathrm{c}}$ Department of Terrestrial Ecology, Netherlands Institute of Ecology (NIOO-KNAW), Droevendaalsesteeg 10, 6708 PB Wageningen, The Netherlands
}

\section{A R T I C L E I N F O}

\section{Article history:}

Received 29 July 2015

Received in revised form

6 November 2015

Accepted 7 November 2015

Available online 27 November 2015

\section{Keywords:}

Artemisia gmelinii

Plant cover

Plant-soil interaction

Soil microbes

Soil aggregates

\begin{abstract}
A B S T R A C T
Plant establishment is widely recognized as an effective way to prevent soil erosion in arid and semiarid ecosystems. Artemisia gmelinii, a pioneering species in many degraded ecosystems in China, is effective in improving soil properties and controlling runoff and soil loss, but mechanisms underlying soil improvement are not well understood. We therefore investigated how the presence and cover of A. gmelinii affect soil physico-chemical properties and soil microbial communities in differently sized soil aggregates in the rhizosphere and inter-plant soil in the Upper Minjiang River arid valley of China. We found that $A$. gmelinii presence significantly improved soil quality in terms of soil structure, water content, aggregate-associated carbon and nutrients, and soil microbial biomass and activities. Interestingly, also inter-plant soils were strongly influenced by adjacent-plant-cover, showing enhanced soil organic carbon, total carbon, nitrogen and phosphorus, and reduced soil bulk density and $\mathrm{pH}$ with increasing A. gmelinii cover in plots. In turn, the A. gmelinii-induced changes in inter-plant soil properties could explain a large part of the observed variation in microbial biomass, carbon and nitrogen. Importantly, effects of the presence and cover of $A$. gmelinii on soil properties were mostly specific for particular aggregate size classes. Specifically, A. gmelinii significantly increased $\mathrm{P}$ accumulation only in small macroaggregates $(250-2000 \mu \mathrm{m})$ illustrating the importance of this aggregate class in terms of plant-mediated phosphorus accumulation, critical for P uptake in this P limited area. Our results thus indicate that $A$. gmelinii not only improves soil physical and microbial conditions in its rhizosphere but also in inter-plant soil, and that increasing $A$. gmelinii cover has the potential to reduce runoff and soil loss and to promote revegetation.
\end{abstract}

๑) 2015 Elsevier Ltd. All rights reserved.

\section{Introduction}

Soil erosion is one of the most formidable threats to the conservation of soil resources in arid and semiarid areas and is one of the main contributing factors to desertification (Rillig et al., 2003). Vegetation plays an important role in improving soil quality and reducing runoff and soil loss (Xu et al., 2009). Presence and type of plant cover can affect resource availability, soil structure, nutrient cycles and microbial community dynamics (Rutigliano et al., 2004;

\footnotetext{
* Corresponding author. 18 Shuangqing Road, Haidian District, Research Center for Eco-Environmental Sciences, Chinese Academy of Sciences, Beijing 100085, China. Tel./fax: +861062849104.

E-mail address: mkm@rcees.ac.cn (K. Ma).

1 Laiye Qu and Yuanyuan Huang contributed equally to the manuscript.
}

Zuazo and Pleguezuelo, 2008; Rutigliano et al., 2009) in semiarid regions.

The patchy distribution of vegetation in dryland results in the well-documented "islands of fertility" and a discontinuous distribution of soil resources, such as water and nutrients (Schlesinger et al., 1996; Aguiar and Sala, 1999). Under shrubs, a higher vegetation cover generally results in increased inputs of carbon and nutrients (Vinton and Burke, 1995), improved soil stability due to the protection from erosion by wind and water, and higher concentrations and activity of microbial populations in vegetated patches than in bare soil (Gallardo and Schlesinger, 1992; Whitford and Sobhy, 1999; Belnap and Phillips, 2001; López et al., 2003). Thus, the mere presence of a living shrub is the dominant driving factor both for soil physical-chemical characteristics and for the activities of microbial communities (Ben-David et al., 2011). Increasing plant cover, moreover, 
intensifies plant-soil interactions that vary with plant type due to differences in qualitative and quantitative input of litter and root exudates (Ludwig et al., 2005). While many studies have documented effects of plants on physico-chemical and microbial properties of rhizosphere soil, effects of increasing plant cover on properties of bare inter-plant soil are less well understood. Insight into such effects is important as the improvement of bare soil, especially its soil fertility and soil stability, is the basis for successful revegetation of seedlings in semi-arid areas (Song et al., 2010). In this study, we therefore investigate not only how the presence of a semi-arid shrub affects the physico-chemical and microbial properties of its rhizosphere soil, but also how plant cover affects the physico-chemical and microbial properties of inter-plant soil.

Restoration ecologists have long recognized the integral role of soil, especially its physical and chemical properties, in the successful revegetation of degraded sites (Heneghan et al., 2008). Soil microbial communities are essential for a wide range of ecosystemlevel processes, such as decomposition, nutrient cycling, soil carbon storage and maintenance of soil structure (Suding et al., 2004; Kardol and Wardle, 2010). It is generally believed that microorganisms increase the stability of aggregates in several ways (Väisänen et al., 2005). For example, fungi alone influence soil aggregation in ecosystems in a variety of ways (Rillig, 2004): their mycelium causes the mechanical enmeshment of soil particles, and fungal compounds can act as binding agents (Rillig, 2004; Väisänen et al., 2005). Soil microbes might therefore serve as key contributors to degraded dryland restoration and their effects may be intertwined with changes in soil aggregate properties. The integration of soil microbial community studies with soil aggregates and physico-chemical studies can thus be regarded as essential in developing in-depth knowledge on belowground dynamics. Hence, in this study we first investigate how vegetation cover affects the size distribution of soil aggregates in inter-plant soils and the physico-chemical properties of each of four differently sized soil aggregate fractions, and then assess how differences in the physicochemical properties of these aggregates are associated with soil microbial properties.

Artemisia gmelinii is a short semiarid shrub with a relatively small leaf area and dense canopy that is effective in improving soil properties and controlling runoff and soil loss (Xu et al., 2009). It is an important pioneering species in degraded regions of the upper Minjiang River valley in China (Li et al., 2008; Xu et al., 2009). In one of these regions, a long-term area of natural restoration was initiated in 1998. The objectives of this study were: (1) to test the effects of $A$. gmelinii on soil physico-chemical and microbial characteristics of both rhizosphere and inter-plant soils, (2) to determine whether an increase in the cover of $A$. gmelinii can improve the quality of adjacent bare inter-plant soil, (3) to better understand how A. gmelinii contributes to the soil improvement of inter-plant soil through effects on physico-chemical and microbial properties of different classes of soil aggregates.

\section{Materials and methods}

\subsection{Study sites}

The study site was located at Maoxian county $\left(31^{\circ} 37^{\prime} 20^{\prime \prime}-31^{\circ} 44^{\prime} 53^{\prime \prime} \mathrm{N}, 103^{\circ} 54^{\prime} 04^{\prime \prime}-103^{\circ} 56^{\prime} 52^{\prime \prime} \mathrm{E}\right)$, which is part of the dry-warm valley of the upper Minjiang River, one of the four principal tributaries of the Yangtze River (Xu et al., 2009; Song et al., 2010). Local topographical features of this area are characterized by mountain peaks $1500-3500 \mathrm{~m}$ above the deep river valley. The mean annual temperature is $11.2^{\circ} \mathrm{C}$, mean annual precipitation is $494 \mathrm{~mm}$ and mean annual evaporation is $1332 \mathrm{~mm}$. The aridity index (the ratio of potential maximum evaporation to rainfall) for this area is within a range from 1.5 to 3.5 , which is typical of semiarid environments (Xu et al., 2009). The predominant soil type is classified as Calcic cambisols (FAO-UNESCO, 1988). The area has been largely devegetated in the past and is now undergoing revegetation. Regional vegetation mainly consists of droughttolerant arid shrubs and sparse grasses (Ma et al., 2004; Xu et al., 2009). A. gmelinii is a predominant semi-shrub in this area and is an important pioneering species associated with arid and semiarid ecosystem restoration in China. It is a relatively short shrub that forms a dense, umbrella-shaped canopy, with branches and leaves that often reach the ground.

\subsection{Experimental design}

Within soils of similar age, topography, parent material, and climate regime, we selected a typical area (ca. $50 \mathrm{~m} \times 50 \mathrm{~m}$ ) predominantly occupied by $A$. gmelinii. Other species in the study area were rare. Thirty $1 \mathrm{~m} \times 1 \mathrm{~m}$ plots were randomly selected. The plots spanned a wide range of values for the projected area (plant cover) of A. gmelinii.

\subsection{Soil sampling}

All of the plots were sampled in July 2010. From each of the thirty plots, ten soil samples were collected. Five samples were taken as close to the centre of the plants as possible and combined into one composite rhizosphere ("under-plant") sample. Five other soil samples per plot were taken from the centre of interspaces between the plants and combined into one composite "inter-plant" sample. This resulted in a total of 60 soil samples for analysis. Soil cores were taken to a depth of $5 \mathrm{~cm}$ with a $5-\mathrm{cm}$ diameter soil corer, excluding the litter layer. Each sample was subsequently divided into three parts. The first part was prepared for determining aggregate fractions, associated total soil carbon (TC), nitrogen (TN) and phosphorus (TP) and water stable aggregates in the $1-2 \mathrm{~mm}$ size class ( $\mathrm{WSA}_{1-2} \mathrm{~mm}$ ). To avoid physical disturbance of the soils, samples of the first part were sealed in aluminum boxes immediately. The second part was sieved to $2 \mathrm{~mm}$ to remove litter and roots. This part was used to measure soil microbial biomass carbon and nitrogen (MBC, MBN), basal respiration (BR), and phospholipid fatty acids (PLFAs). Prior to transport, all soil samples were kept at approximately $4{ }^{\circ} \mathrm{C}$. In the laboratory, all samples were kept at $4{ }^{\circ} \mathrm{C}$ except for the subsamples for PLFA analysis, which were frozen $\left(-80{ }^{\circ} \mathrm{C}\right)$ until further analysis. The third part was also sieved to $2 \mathrm{~mm}$ to remove litter and roots, then was dried at $70{ }^{\circ} \mathrm{C}$ for $48 \mathrm{~h}$ for soil physico-chemical analysis.

\subsection{Percent cover estimation}

Before sampling, a visual percent-plant-cover estimation was made for each of the $1 \mathrm{~m} \times 1 \mathrm{~m}$ plots. This estimate was refined by analyzing photographs from each plot that were taken simultaneously using a Canon EOS 40D (Canon Inc., Japan). The actual plant cover in each photo was determined using Adobe Photoshop CS4 Extended 11.0 (Adobe Systems Inc., USA). We opened the "Magic Want Tool", and clicked a pixel representing the dominant color of plants or soil, respectively, determining the base color. Using the default tolerance setting of 32 , the resulting selections corresponded very well with the distinction between plant and soil area made by eye. We then separately calculated the number of pixels representing plant and soil area, respectively. Plant cover was estimated as follows: 
Plant cover $(\%)=100 *$ Number of plant pixels/

$$
\times(\text { Number of plant }+ \text { soil pixels })
$$

\subsection{Soil chemical and physical characteristics}

Gravimetric water content (GWC) was measured by oven-drying the third category samples at $105{ }^{\circ} \mathrm{C}$ until the weight became constant. Soil $\mathrm{pH}$ and electrical conductivity (EC) were determined in a $1: 2.5(\mathrm{w} / \mathrm{v})$ soil-water suspension. Bulk density (BD) was estimated using the oven-dried soil sample mass and volume. Undrained shear strength was measured in-situ using the inspection vane tester (stand 14.05, Eijkelkamp, Netherlands).

Glomalin, a glycoprotein produced by arbuscular mycorrhizal fungi that plays an important role in soil aggregation, was quantified in soils as glomalin-related soil protein (GRSP). Two GRSP pools, defined as Bradford-reactive soil proteins (BRSPs), were distinguished by their extraction conditions and chosen quantification method (Wright and Upadhyaya, 1998; Rillig, 2004; Janos et al., 2008). The easily extractable BRSPs (EE-BRSPs, EEG) were obtained by autoclaving samples for $30 \mathrm{~min}$ at a pH of 7.0 in $20 \mathrm{~mm}$ citric acid. For total BRSPs (T-BRSPs, TG), the same samples were subjected to sequential $60 \mathrm{~min}$ cycles of autoclaving in $50 \mathrm{~mm}$ citric acid at a $\mathrm{pH}$ of 8.0 , and were then centrifuged at $10,000 \mathrm{~g}$ for $5 \mathrm{~min}$ to remove soil particles. After three cycles of extraction and centrifugation, the supernatant was clear/light yellow, as described by Wright and Upadhyaya (1998). The GRSP concentration in the extracts was determined by Bradford assay, using bovine serum albumin as a standard.

For $\mathrm{WSA}_{1-2} \mathrm{~mm}$ estimation, $4 \mathrm{~g}$ samples of soil aggregates were moistened by capillary action for $10 \mathrm{~min}$. The water stability of aggregates was then measured with a wet-sieving method using the apparatus (Eijkelkamp, Netherlands) and procedure described in Kemper and Rosenau (1986). Percentage of water-stable aggregates was calculated using the mass of aggregated soil remaining after wet sieving and the total mass of aggregates at the beginning (Rillig et al., 2002).

Aggregate size classes were isolated by wet sieving as described by Elliott (1986) and Cambardella and Elliott (1993). The soil samples were gently broken down by hand along natural planes of weakness between aggregates. A series of sieves were used to separate soil into four fractions, large macroaggregates (>2000 $\mu \mathrm{m}$ ), small macroaggregates $(250-2000 \mu \mathrm{m})$, microaggregates $(53-250 \mu \mathrm{m})$ and non-aggregated silt and clay particles $(<53 \mu \mathrm{m})$ (Six et al., 2000). Soil organic carbon (SOC) was measured with a fully automatic UV-Persuate organic carbon analyzer (Tekmar-Dohrmann, Mason OH, USA). Total soil nitrogen (TN) and total soil carbon (TC) were determined by combustion at $1024{ }^{\circ} \mathrm{C}$ and measured in a Vario EL III elemental analyzer (Elementar $\mathrm{GmbH}$, Hanau, Germany). Total phosphorus (TP) was measured calorimetrically after wet digestion with $\mathrm{H}_{2} \mathrm{SO}_{4}$ plus $\mathrm{HClO}_{4}$.

\subsection{Microbial community properties}

Microbial biomass carbon (MBC) and nitrogen (MBN) were determined using $10 \mathrm{~g}$ of soil and the fumigation-extraction procedure (Macdonald et al., 2009). Total C in the $0.5 \mathrm{M} \mathrm{K}_{2} \mathrm{SO}_{4}$ solution was measured with a UV-Persuate TOC-5000A soluble $\mathrm{C}$ analyzer (Elementar $\mathrm{GmbH}$, Hanau, Germany), and a $K_{\mathrm{EC}}$-factor of 0.43 was used in calculations; the $\mathrm{N}$ content was measured using a method described by Brookes et al. (1985) and a $K_{\mathrm{EN}}$-factor of 0.54 was used.

Microbial community structure was assessed by PLFA analysis using a modified method (White et al., 1979) based on that of Bligh and Dyer (Bligh and Dyer, 1959). Soil samples from each site were freeze-dried and finely ground; $4 \mathrm{~g}$ of each sample were used for extracting PLFAs. The separated fatty acid methyl-esters were identified and quantified by GC-MS (HP6890/MSD5973) using methyl nonadecanoate (19:0) as the internal standard. For each sample, the abundance of individual fatty acid methyl-esters was expressed as nmol PLFA ${ }^{-1}$ soil. The fatty acid nomenclature used was that described by Frostegård et al. (1993).

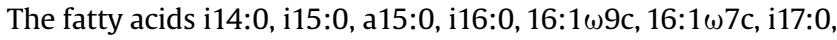

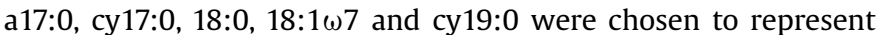
bacterial PLFAs (Frostegård et al., 1993; Macdonald et al., 2009). The

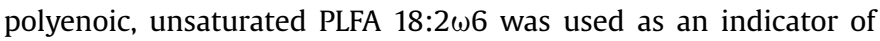
fungal biomass. The monoenoic unsaturated PLFA 16:1 w5c was used to estimate the arbuscular mycorrhizal fungal biomass. The PLFAs i14:0, i15:0, a15:0, i16:0, i17:0, a17:0 and 18:0 were chosen to represent Gram-positive bacteria $\left(\mathrm{G}^{+}\right)$. The monoenoic and cyclo-

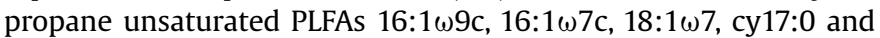
cy19:0 were chosen to represent Gram-negative bacteria $\left(\mathrm{G}^{-}\right)$ (Ewing et al., 2007; Aanderud et al., 2008; Macdonald et al., 2009). The ratio of fungal: bacterial PLFA was used as an indicator of changes in the relative abundance of these two microbial groups (Bardgett et al., 1996).

Basal respiration (BR) was determined using $25 \mathrm{~g}$ soil (dry weight) placed in sealed flasks, moistened to $60 \%$ of its water holding capacity and incubated in the dark at $25{ }^{\circ} \mathrm{C} . \mathrm{CO}_{2}$ released was measured with an $\mathrm{IR} \mathrm{CO}_{2}$ detector.

\subsection{Statistical analysis}

To quantify the effect of the presence of A. gmelinii on physicochemical and microbial soil properties, we calculated the "underplant: inter-plant ratio" $(\mathrm{R})$ for each plot for each of the parameters studied. For each parameter, the ratio was calculated by dividing two values per plot: the mean value for the five under-plant samples and the mean value for the five inter-plant samples (see 2.3 ). Paired-sample t-tests at a confidence interval of $95 \%$ were used to determine the significance of differences between underplant and inter-plant soils. We classified plant cover into three classes, low $(<30 \%, \mathrm{n}=6)$, medium $(30-60 \%, \mathrm{n}=14)$ and high ( $>60 \%, n=10$ ). One-way ANOVA was used to determine whether there were significant differences between different plant cover classes in soil physico-chemical and microbial parameters. Since our main interest was in how A. gmelinii cover affects properties of inter-plant soil, these analyses were restricted to inter-plant soils. To test whether the distribution of soil aggregate size classes in inter-plant soil differed among plant cover classes, we first calculated the percentages that each of the four size classes of soil aggregates contributed to each of the thirty inter-plant samples and then used one-way ANOVAs for each of the size classes to test whether their proportion differed among the three plant cover classes. ANOVAs were followed by post-hoc analysis using Tukey's HSD tests to test which of the cover classes significantly differed from each other. All these analyses were conducted using SPSS13.0 (SPSS Institute Inc., 2002).

Multivariate analyses (linear model redundancy analysis, RDA) were used to test and visualize associations between soil characteristics and microbial characteristics among the inter-plant samples from the thirty plots. RDA plots can be interpreted quantitatively using the length of the arrow to indicate how much variance among samples is explained by that factor; the direction of the arrows for individual soil property parameters indicates an increasing concentration of that factor. The microbial group arrows pointing in approximately the same direction as the soil property parameter arrows indicate a high positive correlation (the longer the microbial group arrow, the stronger the relationship; 
Macdonald et al., 2009). When necessary, data was log transformed. The significance of the canonical axis was tested using the Monte Carlo permutation test. All multivariate techniques were performed with CANOCO 4.5 (Biometris, Wageningen, the Netherlands).

\section{Results}

\subsection{Effects of the presence of A. gmelinii on belowground properties}

The paired-sample t-test (Table 1) shows that the presence of A. gmelinii significantly increased gravimetric water content (GWC), water stable aggregates in the $1-2 \mathrm{~mm}$ size class $\left(\mathrm{WSA}_{1-2 \mathrm{~mm}}\right.$ ), easily-extractable glomalin (EEG), total glomalin (TG) and soil organic carbon, whereas it lowered shear strength (SS) and bulk density (BD). The $\mathrm{pH}$ and electrical conductivity (EC) were not significantly affected. Effects of $A$. gmelinii on total soil carbon (TC) and phosphorus (TP) varied among soil aggregate size classes. TC was significantly higher in under-plant soils than in inter-plant soils in large macroaggregates $(>2000 \mu \mathrm{m})$, small macroaggregates $(250-2000 \mu \mathrm{m})$, and microaggregates $(53-250 \mu \mathrm{m})$, while it remained unchanged in non-aggregated silt and clay particles $(<53 \mu \mathrm{m})$. TP was significantly higher in under-plant soil than interplant soil for small macroaggregates only $(P<0.001)$. TN was significantly higher in under-plant soils for all size classes. $\mathrm{R}$ values (under-plant: inter-plant) of TN were larger than those of TC for any given size class. For TC and TP, the highest $\mathrm{R}$ values were observed in small macroaggregates; for TN the highest $\mathrm{R}$ value was observed in microaggregates.

For soil microbial communities, all the microbial parameters studied had significantly larger values in under-plant soils than in inter-plant soils. This was most evident for microbial biomass nitrogen, that showed the highest mean under-plant to inter-plant

\section{Table 1}

Soil physico-chemical properties (means) of rhizosphere (under-plant) and interplant soil. The paired-sample T-test indicates significance of differences between under-plant and inter-plant soils. Abbreviations are as follows: $\mathrm{R}=$ averaged value of under-plant to inter-plant ratios, $\mathrm{SS}=$ shear strength, $\mathrm{EC}=$ electrical conductivity, $\mathrm{GWC}=$ gravimetric water content, $\mathrm{BD}=$ bulk density, $\mathrm{WSA}_{1-2 \mathrm{~mm}}=$ water stable aggregates in the $1-2 \mathrm{~mm}$ size class, $\mathrm{EEG}=$ easily-extractable glomalin, $\mathrm{TG}=$ total glomalin, $\mathrm{SOC}=$ soil organic carbon, $\mathrm{TC}=$ total soil carbon, $\mathrm{TN}=$ total soil nitrogen, $\mathrm{TP}=$ total phosphorus. The numerals 1, 2, 3, 4 for TC, TN and TP refer to the four soil aggregate size classes: $>2000 \mu \mathrm{m}, 2000-250 \mu \mathrm{m}, 250-53 \mu \mathrm{m}$, and $<53 \mu \mathrm{m}$, respectively.

\begin{tabular}{|c|c|c|c|c|c|c|}
\hline & Under-plant & Inter-plant & $\mathrm{R}$ & $\mathrm{t}$ & $\mathrm{df}$ & $\mathrm{P}$ \\
\hline SS kPa & 20.156 & 39.917 & 0.521 & -11.047 & 29 & $<0.001$ \\
\hline $\mathrm{pH}$ & 8.389 & 8.441 & 0.994 & -1.572 & 29 & 0.127 \\
\hline $\mathrm{EC} \mu \mathrm{S} \mathrm{cm}^{-1}$ & 417.50 & 464.23 & 1.058 & -1.028 & 29 & 0.312 \\
\hline GWC \% & 11.230 & 9.916 & 1.132 & 3.917 & 29 & 0.001 \\
\hline $\mathrm{BD} \mathrm{g} \mathrm{dm}^{-3}$ & 88.497 & 105.452 & 0.846 & -6.388 & 29 & $<0.001$ \\
\hline $\mathrm{WSA}_{1-2} \mathrm{~mm} \%$ & 68.348 & 56.831 & 1.320 & 3.825 & 29 & 0.001 \\
\hline EEG mg/g & 2.174 & 1.758 & 1.564 & 3.547 & 29 & 0.001 \\
\hline $\mathrm{TG} \mathrm{mg} / \mathrm{g}$ & 3.909 & 3.109 & 1.594 & 3.836 & 29 & 0.001 \\
\hline $\mathrm{SOC} \mathrm{mg} / \mathrm{g}$ & 40.807 & 28.851 & 1.541 & 5.760 & 27 & $<0.001$ \\
\hline $\mathrm{TC} 1 \mathrm{mg} / \mathrm{g}$ & 43.844 & 37.092 & 1.220 & 4.327 & 29 & $<0.001$ \\
\hline $\mathrm{TC} 2 \mathrm{mg} / \mathrm{g}$ & 53.082 & 42.291 & 1.33 & 5.328 & 29 & $<0.001$ \\
\hline $\mathrm{TC} 3 \mathrm{mg} / \mathrm{g}$ & 38.160 & 32.387 & 1.267 & 3.215 & 28 & 0.003 \\
\hline $\mathrm{TC} 4 \mathrm{mg} / \mathrm{g}$ & 27.801 & 27.077 & 1.052 & 0.744 & 28 & 0.463 \\
\hline $\mathrm{TN} 1 \mathrm{mg} / \mathrm{g}$ & 2.798 & 2.197 & 1.443 & 4.687 & 29 & $<0.001$ \\
\hline $\mathrm{TN} 2 \mathrm{mg} / \mathrm{g}$ & 3.589 & 2.670 & 1.639 & 5.331 & 29 & $<0.001$ \\
\hline TN3 mg/g & 2.516 & 1.919 & 1.655 & 3.860 & 28 & 0.001 \\
\hline $\mathrm{TN} 4 \mathrm{mg} / \mathrm{g}$ & 1.819 & 1.611 & 1.243 & 2.235 & 28 & 0.034 \\
\hline $\mathrm{TP} 1 \mathrm{mg} / \mathrm{g}$ & 0.677 & 0.702 & 0.985 & -1.029 & 29 & 0.312 \\
\hline $\mathrm{TP} 2 \mathrm{mg} / \mathrm{g}$ & 0.700 & 0.603 & 1.148 & 4.270 & 29 & $<0.001$ \\
\hline TP3 mg/g & 0.658 & 0.652 & 0.999 & -0.636 & 28 & 0.53 \\
\hline $\mathrm{TP} 4 \mathrm{mg} / \mathrm{g}$ & 0.618 & 0.598 & 1.017 & -0.063 & 26 & 0.95 \\
\hline
\end{tabular}

ratio of $4.59(\mathrm{P}<0.001)$ (Table 2$)$. Evidently, plant presence promoted microbial activity (basal respiration) and microbial biomass.

\subsection{Influence of plant cover on inter-plant soil properties}

We found that the proportion of (large and small) macroaggregates significantly increased with plant cover $\left(\mathrm{F}_{[2,27]}=4.03\right.$, $\mathrm{P}<0.05)$ at the expense of the microaggregates $\left(\mathrm{F}_{[2,27]}=7.53\right.$, $\mathrm{P}<0.01$ ), while the non-aggregated soil fraction was not significantly affected by plant cover $\left(\mathrm{F}_{[2,27]}=1.52, \mathrm{P}=0.24\right)$ (Fig. $\left.1 \mathrm{~A}\right)$. The effect of $A$. gmelinii cover on total soil carbon (TC) and phosphorus (TP) in inter-plant soils differed among soil aggregate size classes. TC increased from the low to the high cover class in large macroaggregates $(>2000 \mu \mathrm{m})$, small macroaggregates $(250-2000 \mu \mathrm{m})$, and microaggregates $(53-250 \mu \mathrm{m})$, but not in non-aggregated silt and clay particles $(<53 \mu \mathrm{m})$ (Fig. 1B). Total soil nitrogen (TN) increased from the low to the high cover class in all aggregate size classes (Fig. 1C). In all of the cover classes studied, the small macroaggregates harbored the highest $\mathrm{TC}$ and $\mathrm{TN}$ concentrations (Fig. 1B and C). TP was significantly higher in the high cover class than in the low and medium classes in non-aggregated silt and clay particles only (Fig. 1D). Easily-extractable glomalin, total glomalin and soil organic carbon were highest in the high cover class (Fig. 2A and $\mathrm{B}$ ), whereas $\mathrm{pH}$ and bulk density were significantly lower in medium classes compared to the low cover class (Fig. 2C and D). Shear strength and water stable aggregates in the 1-2 mm size class were not significantly affected by adjacent plant cover (data not shown).

Microbial biomass nitrogen was lower in the low cover class compared to the medium and high classes, while microbial biomass carbon was lower both in the low and medium classes compared to the high class of plant (Fig. 3A and B). Fungal biomass did not significantly differ between cover classes, whereas bacterial biomass was significantly higher in the high cover class compared to the low cover class (Fig. 3C). But there was not significant differences for fungal biomass (Fig. 3D). Consequently, the fungal: bacterial ratio (Fig. 3E) was significantly lower in the high cover than in the low cover plots. The activity of microbial communities (reflected by basal respiration) was also significantly lower in low cover plots (Fig. 3F).

\subsection{Correlations among belowground characteristics in inter-plant soil}

The soil physico-chemical parameter that was most strongly associated with a soil microbial parameter in inter-plant soil strongly depended on the specific microbial parameter and soil aggregate class that was considered. Microbial biomass carbon was most strongly associated with high TC in non-aggregated silt and clay particles $(<53 \mu \mathrm{m})$; Microbial biomass nitrogen was closely related with high TN in non-aggregated silt and clay particles $(<53 \mu \mathrm{m})$ and easily-extractable glomalin, and negatively with bulk density and pH. Arbuscular mycorrhiza, bacteria, Gram-positive bacteria and Gram-negative bacteria were closely related to TP in small macroaggregates (250-2000 $\mu \mathrm{m}$ ) and TN in microaggregates $(53-250 \mu \mathrm{m})$. Fungal biomass was closely related to water stable aggregates in the $1-2 \mathrm{~mm}$ size class, TC in microaggregates (53-250 $\mu \mathrm{m}$ ), and electrical conductivity (Fig. 4).

\section{Discussion}

\subsection{Improvement of soil quality by A. gmelinii establishment}

Comparisons of soil characteristics under plants with inter-plant soils revealed that the presence of $A$. gmelinii evidently improved 
Table 2

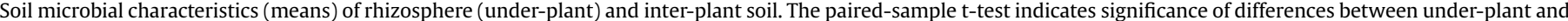

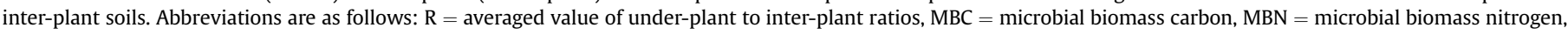

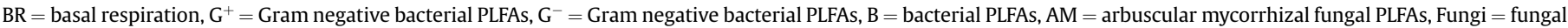
PLFA.

\begin{tabular}{|c|c|c|c|c|c|c|c|c|}
\hline & $\mathrm{MBC} \mathrm{mg} / \mathrm{kg}$ & $\mathrm{MBN} \mathrm{mg} / \mathrm{kg}$ & $\mathrm{BR} \mu \mathrm{gCO} 2-\mathrm{C} / \mathrm{g} / \mathrm{h}$ & $\mathrm{G}^{+} \mathrm{nmol} / \mathrm{g}$ & $\mathrm{G}^{-} \mathrm{nmol} / \mathrm{g}$ & $\mathrm{B} \mathrm{nmol} / \mathrm{g}$ & $\mathrm{AM} \mathrm{nmol} / \mathrm{g}$ & $\mathrm{F} \mathrm{nmol} / \mathrm{g}$ \\
\hline Under-plant & 587.87 & 39.97 & 0.520 & 54.27 & 30.78 & 85.05 & 12.46 & 8.25 \\
\hline Inter-plant & 340.57 & 8.76 & 0.265 & 36.06 & 18.21 & 54.26 & 6.94 & 4.88 \\
\hline $\mathrm{R}$ & 1.943 & 4.594 & 2.301 & 3.112 & 2.774 & 2.868 & 2.508 & 2.230 \\
\hline $\mathrm{t}$ & -10.176 & -11.603 & -9.009 & -3.748 & -4.614 & -4.099 & -4.913 & -4.946 \\
\hline df & 29 & 29 & 29 & 28 & 28 & 28 & 26 & 28 \\
\hline $\mathrm{P}$ & $<0.001$ & $<0.001$ & $<0.001$ & $<0.001$ & $<0.001$ & $<0.001$ & $<0.001$ & $<0.001$ \\
\hline
\end{tabular}

soil quality. Soil water deficiency was ameliorated and soil organic carbon was significantly increased by plant establishment. TC and TN accumulated most strongly under plants. These results demonstrate the important role of $A$. gmelinii in improving the soil quality in this semi-arid area. The magnitude of the carbon and nutrient accumulation under plants differed among differently sized soil aggregates. The aggregate hierarchy model predicts that $C$ concentration will increase with increasing aggregate size class because larger aggregate size classes are composed of smaller aggregate size classes plus organic binding agents (Tisdall and Oades, 1982; Six et al., 2000). In our study, the concentrations of TC and TN were highest in small macroaggregates $(250-2000 \mu \mathrm{m})$, in which the accumulation of carbon and nitrogen under plants was most evident. In cultivated soils, also total $\mathrm{P}$ is expected to increase with increasing soil aggregate size. Wright (2009) found that aggregation increased $P$ sequestration in humic-fulvic acid and residual fractions and that P storage in organic pools increased with increasing aggregate size. In our study, the magnitude of changes in $\mathrm{P}$ concentrations with aggregate size were relatively small. But the presence of $A$. gmelinii still significantly increased $\mathrm{P}$ accumulation in small macroaggregates $(250-2000 \mu \mathrm{m})$. Therefore, among soil size classes, the small macroaggregates may be important in terms of phosphorus accumulations, which may be closely related to $\mathrm{P}$ uptake in this semiarid area. This indicates the potential importance of macroaggregates for rehabilitation, since low P concentrations and water content are the most limiting factors for plant growth in this semiarid valley of the Upper Mingjiang River (Xu et al., 2009; Song et al., 2010).

Increases in organic carbon content generally enhance the soil's macroaggregate content and macroporosity, and thereby reduce its bulk density (Dunkerley and Brown, 1995). Aggregate stability could determine the capacity of aggregates to resist the effects of water and rainfall. Increases in water stable aggregates in the 1-2 mm size class $\left(\mathrm{WSA}_{1-2} \mathrm{~mm}\right.$ ) are generally associated with more recalcitrance to runoff and less soil loss. In our study, A. gmelinii presence decreased bulk density values in the surface soils, increased $\mathrm{WSA}_{1-2} \mathrm{~mm}$ values, and increased macroaggregate (large macroaggregates and small macroaggregates) contents of carbon
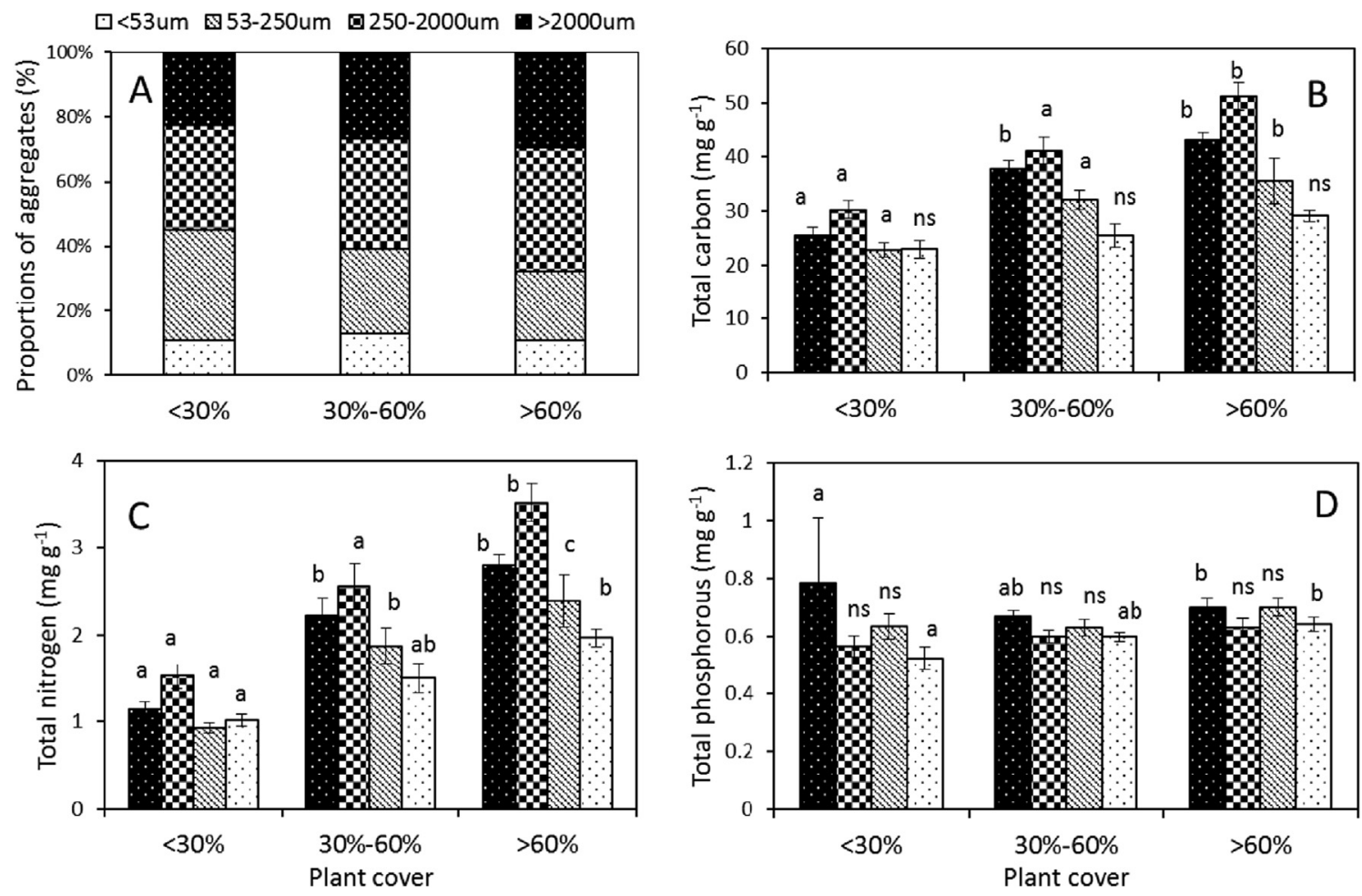

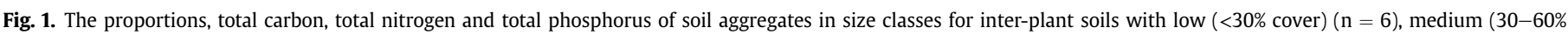

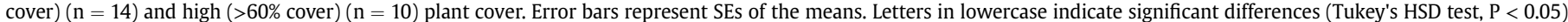

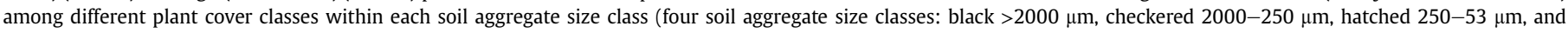
stippled $<53 \mu \mathrm{m}$ ). Abbreviations are the same as Table 1. 

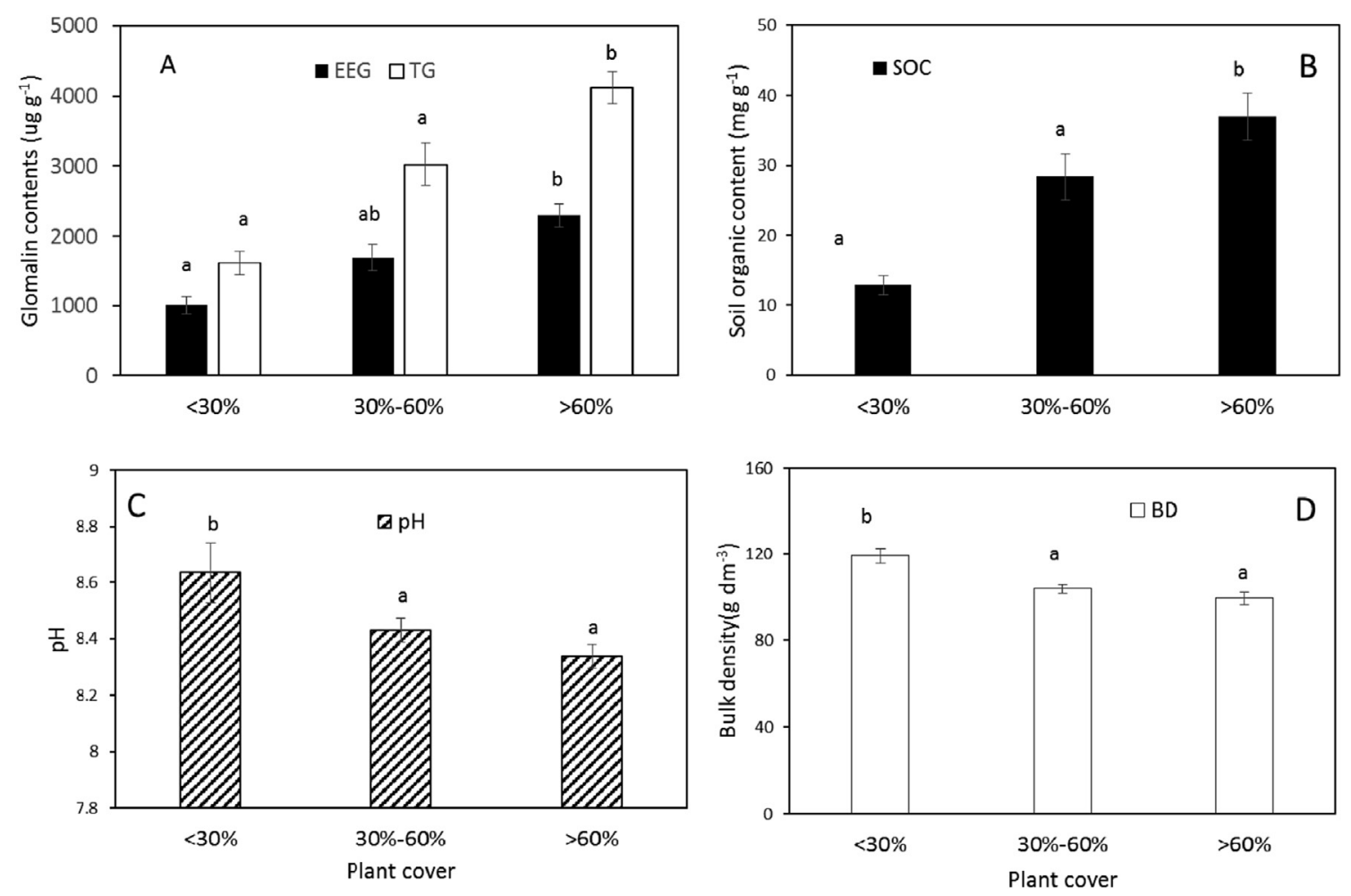

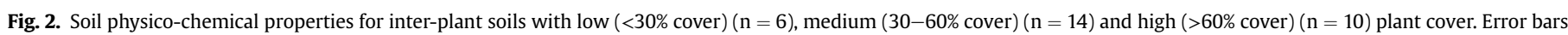

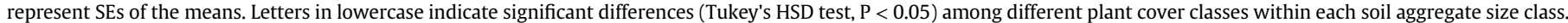
Abbreviations are the same as Table 1.

and nitrogen. Therefore, our results indicate that $A$. gmelinii generally improved soil physical conditions and the potential in reducing runoff and soil loss. The only exception to this was the effect of $A$. gmelinii on sheer strength, an indicator of resistance to soil erosion, which was actually lower for under-plant than for inter-plant soil. However, this effect may have been be due to the higher soil water content under plants, that often results in decreased sheer strength (Fan and Su, 2008), and does not necessarily indicate a negative impact on reducing runoff and soil loss. Interestingly, we found that the small macroaggregates contained the highest concentrations of total carbon and nitrogen of all soil aggregate size classes in all three cover classes studied. This indicates this size aggregates maybe important in terms of carbon and nitrogen related dynamics in our study site.

In addition to soil carbon and nutrients under plants, soil microbial biomass was also strongly accumulated under $A$. gmelinii plants, and the extent of their accumulation was larger than that of total soil carbon and nitrogen (Tables 1 and 2), indicating the high sensitivity of microbial parameters to A. gmelinii presence and growth, consistent with other studies (Panikov, 1999). Through intensified microbial activities, A. gmelinii could promote soil carbon, nitrogen and phosphorous dynamics, which is expected to create a positive feedback to the plant, and to further increase macroaggregate levels and to enhance soil stability.

\subsection{Influence of A. gmelinii cover on inter-plant soils}

Our results clearly show that not only soil directly under plants, but also inter-plant soils were influenced by the presence of A. gmelinii and that effects on inter-plant soils generally increased with plant cover. With increasing plant cover, the proportion of macroaggregates increases at the expense of microaggregates on inter-plant soil. The proportion of macroaggregates is a good indicator to represent the ability of soil to resist soil erosion (Barthès and Roose 2002). Our results indicate the improvement of soil structure due to the effects of adjacent increasing plant cover on increasing the proportion of macroaggregates in inter-plant soil. Total soil carbon and nitrogen in inter-plant soils increased with increasing plant cover and the magnitude of the change differed among soil size classes (Fig. 2), even though the values of these parameters were still lower compared to those in underplant soils.

Bulk density is an important characteristic that affects key soil functions such as water-holding capacity, infiltrability, aeration, plant germination and root growth (Moraa and Lázarob, 2014). Higher plant cover significantly reduced soil bulk density of interplant soil, which strongly indicates an improvement in soil physical properties (Fig. 1). The shear strength and water stable aggregates in the $1-2 \mathrm{~mm}$ size class ( $\mathrm{WSA}_{1-2} \mathrm{~mm}$ ) did not significantly differ among cover classes, although the percent content of WSA $_{1-2} \mathrm{~mm}$ in large macroaggregates and small macroaggregates increased from low to high cover classes (data not shown). In our study, both easily extractable glomalin (EEG) and total glomalin (TG) significantly correlated with soil organic carbon, while no significant correlation could be found between water stable aggregates in the 1-2 $\mathrm{mm}$ size class and soil organic carbon. However, A. gmelinii cover reduced soil $\mathrm{pH}$, which means the alkali stress in soils in this area may be ameliorated.

Microbial biomass and activity in inter-plant soils increased with increasing plant cover (Fig. 3). This is expected to alter carbon and nutrient dynamics among soil size classes and further accelerate soil aggregation. Younger and more labile organic matter is postulated to be more prevalent in macroaggregates than in microaggregates (Tisdall and Oades, 1982). In general, microbial communities associated with larger aggregate size classes (large and small macroaggregates) were found to have a significantly 

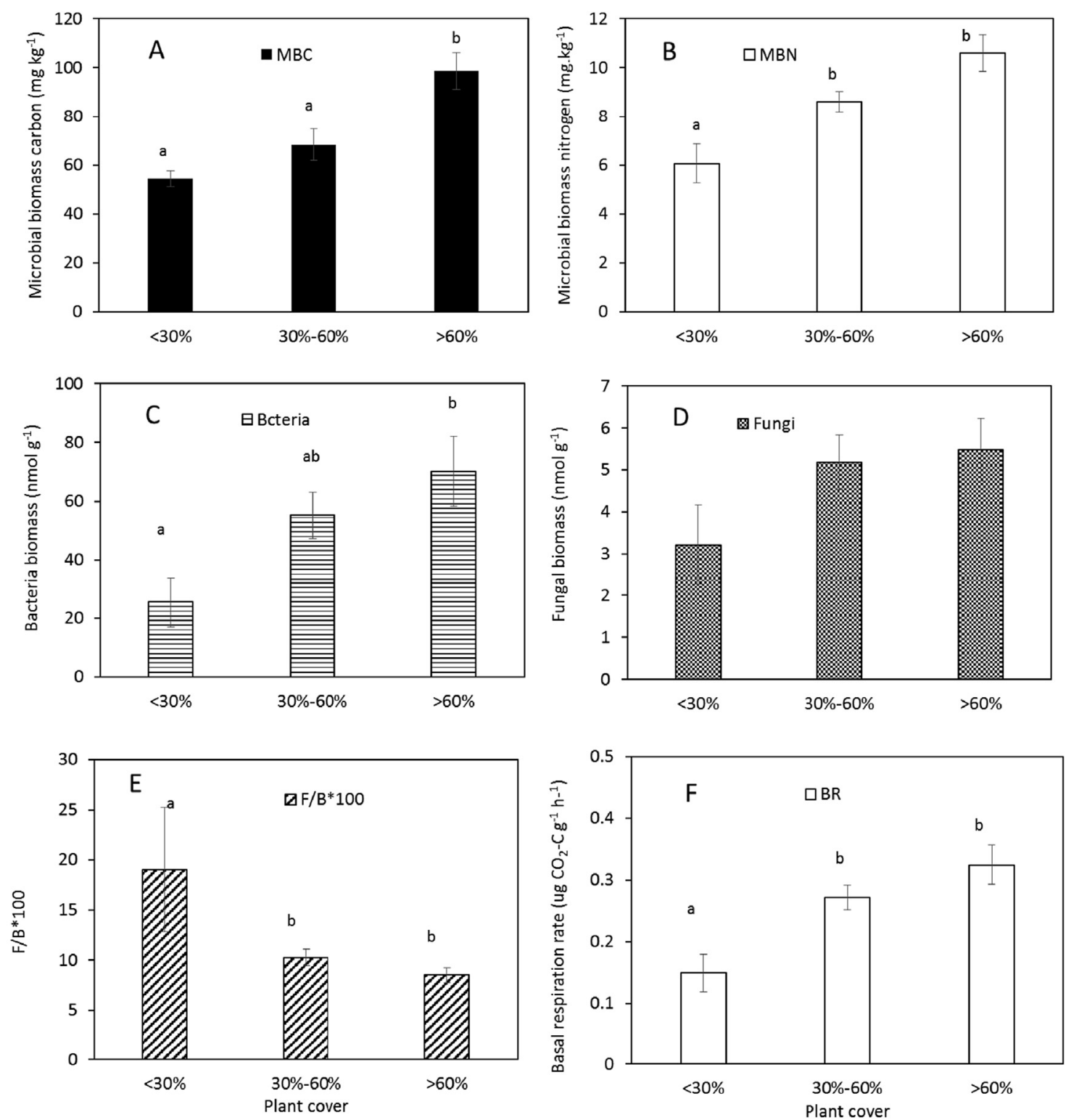

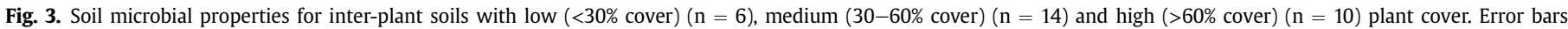

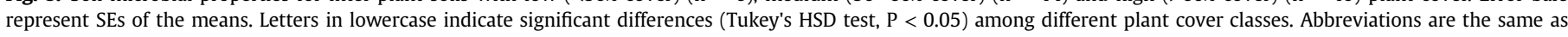
Table 2.

faster respiratory response than the communities associated with microaggregates (Väisänen et al., 2005). Unfortunately, we could not separate the microbial biomass of soil size classes in this study.

Our study clearly demonstrates that the physico-chemical properties that drive soil microbial groups and activities strongly depend on the microbial parameters that are considered. Basal respiration was primarily associated with easily extractable and total glomalin (related to soil organic matter), and total soil carbon and nitrogen in large macroaggregates and small macroaggregates. By contrast, microbial biomass carbon and nitrogen were closely related to total soil carbon and nitrogen in non-aggregated silt and clay particles, and to soil organic matter. Therefore, total carbon and nitrogen in large macroaggregates and small macroaggregates are important for microbial activity, whereas total carbon and nitrogen in non-aggregated silt and clay particles are important for microbial biomass accumulation in our system. Biomass of arbuscular mycorrhizal fungi and Gram-positive and Gram-negative bacteria in inter-plant soils were most strongly associated with TP in small macroaggregates $(250-2000 \mu \mathrm{m})$ and $\mathrm{TN}$ in microaggregates $(53-250 \mu \mathrm{m})$. By contrast, fungal biomass was mainly constrained by TC in microaggregates $(53-250 \mu \mathrm{m})$ and was strongly associated with water stable aggregates in the $1-2 \mathrm{~mm}$ size class.

In conclusion, we found that A. gmelinii establishment significantly increased aggregate-associated carbon and nutrients, accumulated soil microbial biomass and intensified microbial activities, and improved soil physical quality, which would further increase the potential of $A$. gmelinii in reducing runoff and soil loss. The inter-plant soils were strongly influenced by adjacent $A$. gmelinii cover, resulting in gradually increasing soil quality with increasing cover.

Land degradation is a serious issue in arid and semi-arid regions of China. A. gmelinii is a promising species to use as the target native plant to naturally rehabilitate the degraded region not only in the upper Minjiang River valley but also in other semi-arid regions in 


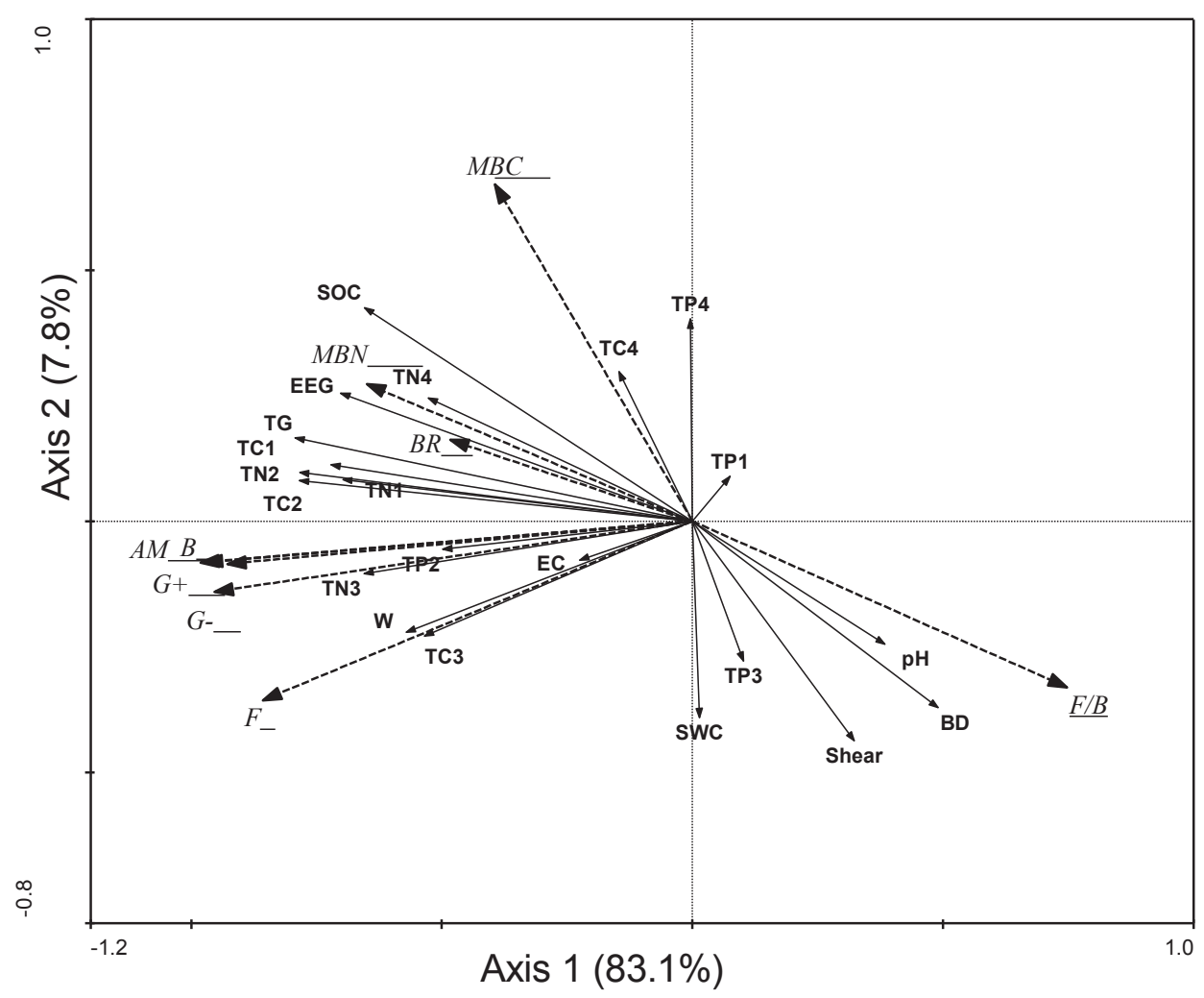

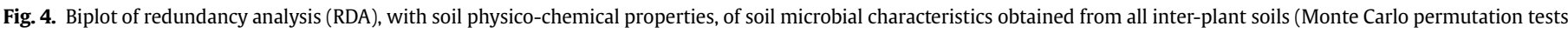
$\mathrm{P}=0.004)$. The solid arrows represent soil physico-chemical properties and the dotted arrows represent different microbial parameters.

China. In a broader perspective, our results indicate that carefully selected native plant species may play an important role in rehabilitation of degraded soil systems in semi-arid regions, providing a valuable alternative for the current tendency to plant introduced tree species for that purpose.

\section{Acknowledgments}

This research was supported by National Natural Science Foundation of China (No. 31170581) and China Scholarship Council (No. 201404910206) to Dr. Laiye Qu.

\section{References}

Aanderud, Z.T., Shuldman, M.I., Drenovsky, R.E., Richards, J.H., 2008. Shrub-interspace dynamics alter relationships between microbial community composition and belowground ecosystem characteristics. Soil Biology \& Biochemistry 40, 2206-2216.

Aguiar, M.R., Sala, O.E., 1999. Patch structure, dynamics and implications for the functioning of arid ecosystems. Trends in Ecology \& Evolution 14, 273-277.

Bardgett, R.D., Hobbs, P.J., Frostegard, A., 1996. Changes in soil fungal: bacterial biomass ratios following reductions in the intensity of management of an upland grassland. Biology and Fertility of Soils 22, 261-264.

Barthes, B., Roose, E., 2002. Aggregate stability as an indicator of soil susceptibility to runoff and erosion; validation at several levels. Catena 47,133-149.

Belnap, J., Phillips, S.L., 2001. Soil biota in an ungrazed grassland: response to annual grass (Bromus Tectorum) invasion. Ecological Applications 11, 1261-1275.

Ben-David, E.A., Zaady, E., Sher, Y., Nejidat, A., 2011. Assessment of the spatial distribution of soil microbial communities in patchy arid and semi-arid landscapes of the Negev Desert using combined PLFA and DGGE analyses. FEMS Microbiology Ecology 76, 492-503.

Bligh, E.G., Dyer, W.J., 1959. A rapid method of total lipid extraction and purification. Canadian Journal of Biochemistry and Physiology 37, 911-917.

Brookes, P.C., Landman, A., Pruden, G., Jenkinson, D.S., 1985. Chloroform fumigation and the release of soil nitrogen - a rapid direct extraction method to measure microbial biomass nitrogen in soil. Soil Biology \& Biochemistry 17, 837-842.

Cambardella, C.A., Elliott, E.T., 1993. Methods for physical separation and characterization of soil organic matter fractions. Geoderma 56, 449-457.
Dunkerley, D.L., Brown, K.J., 1995. Runoff and run on areas in a patterned chenopod shrubland, arid western New South Wales, Australia: characteristics and origin. Journal of Arid Environments 30, 41-55.

Elliott, E.T., 1986. Aggregate structure and carbon, nitrogen, and phosphorus in native and cultivated soils. Soil Science Society of America Journal 50, 627-633.

Ewing, S.A., Southard, R.J., Macalady, J.L., Hartshorn, A.S., Johnson, M.J., 2007. Soil microbial fingerprints, carbon, and nitrogen in a Mojave Desert creosote-bush ecosystem. Soil Science Society of America Journal 71, 469-475.

Fan, C.C., Su, C.F., 2008. Role of roots in shear strength of root-reinforced soils and with high moisture content. Ecological Engineering 33, 157-166.

Frostegård, Å., Bååth, E., Tunlio, A., 1993. Shifts in the structure of soil microbial communities in limed forests as revealed by phospholipid fatty acid analysis. Soil Biology \& Biochemistry 25, 723-730.

Gallardo, A., Schlesinger, W.H., 1992. Carbon and nitrogen limitations of soil microbial biomass in desert ecosystems. Biogeochemistry 18, 1-17.

Heneghan, L., Miller, S.P., Baer, S., Callaham, M.A., Montgomery, J., PavaoZuckerman, M., Rhoades, C.C., Richardson, S., 2008. Integrating soil ecological knowledge into restoration management. Restoration Ecology 16, 608-617.

Janos, D.P., Garamszegi, S., Beltran, B., 2008. Glomalin extraction and measurement. Soil Biology \& Biochemistry 40, 728-739.

Kardol, P., Wardle, D.A., 2010. How understanding aboveground-belowground linkages can assist restoration ecology. Trends in Ecology \& Evolution 25, 670-679.

Kemper, W.D., Rosenau, R.C., 1986. Aggregate stability and size distribution. In: Klute, A. (Ed.), Methods of Soil Analysis (Part I). American Society of Agronomy, Madison, WI, pp. 425-442.

Li, S.Q., Yang, B.S., Wu, D.M., 2008. Community succession analysis of naturally colonized plants on coal gob piles in Shanxi mining areas, China. Water Air and Soil Pollution 193, 211-228.

Lopez, N.I., Austin, A.T., Sala, O.E., Méndez, B.S., 2003. Controls on nitrification in a water-limited ecosystem: experimental inhibition of ammonia-oxidising bacteria in the Patagonian steppe. Soil Biology \& Biochemistry 35, 1609-1613.

Ludwig, J.A., Wilcox, B.P., Breshears, D.D., Tongway, D.J., Imeson, A.C., 2005. Vegetation patches and runoff-erosion as interacting ecohydrological processes in semiarid landscapes. Ecology 86, 288-297.

Ma, K.M., Fu, B.J., Liu, S.L., Guan, W.B., Liu, G.H., Lu, Y.H., Anand, M., 2004. Multiplescale soil moisture distribution and its implications for ecosystem restoration in an Arid River valley, China. Land Degradation \& Development 15, 75-85.

Macdonald, C.A., Thomas, N., Robinson, L., Tate, K.R., Ross, D.J., Dando, J., Singh, B.K. 2009. Physiological, biochemical and molecular responses of the soil microbia community after afforestation of pastures with Pinus radiata. Soil Biology \& Biochemistry 41, 1642-1651. 
Moraa, J.L., Lázarob, R., 2014. Seasonal changes in bulk density under semiarid patchy vegetation: the soil beats. Geoderma 235-236, 30-38.

Panikov, N.S., 1999. Understanding and prediction of soil microbial community dynamics under global change. Applied Soil Ecology 11, 161-176.

Rillig, M.C., 2004. Arbuscular mycorrhizae, glomalin, and soil aggregation. Canadian Journal of Soil Science 84, 355-363.

Rillig, M.C., Wright, S.F., Eviner, V.T., 2002. The role of arbuscular mycorrhizal fungi and glomalin in soil aggregation: comparing effects of five plant species. Plant and Soil 238, 325-333.

Rillig, M.C., Maestre, F.T., Lamit, L.J., 2003. Microsite differences in fungal hyphal length, glomalin, and soil aggregate stability in semiarid Mediterranean steppes. Soil Biology \& Biochemistry 35, 1257-1260.

Rutigliano, F.A., D'Ascoli, R. De Santo, A.V., 2004. Soil microbial metabolism and nutrient status in a Mediterranean area as affected by plant cover. Soil Biology \& Biochemistry 36, 1719-1729.

Rutigliano, F.A. Castaldi, S., D'Ascoli, R., Papa, S., Carfora, A., Marzaioli, R. Fioretto, A., 2009. Soil activities related to nitrogen cycle under three plant cover types in Mediterranean environment. Applied Soil Ecology 43, 40-46.

Schlesinger, W.H., Raikes, J.A., Hartley, A.E., Cross, A.F., 1996. On the spatial pattern of soil nutrients in desert ecosystems. Ecology 77, 364-374.

Six, J., Paustian, K., Elliott, E.T., Combrink, C., 2000. Soil structure and organic matter: I. Distribution of aggregate-size classes and aggregate-associated carbon. Soil Science Society of America Journal 64, 681-689.

Song, C.J., Ma, K.M., Qu, L.Y., Liu, Y., Xu, X.L., Fu, B.J., Zhong, J.F., 2010. Interactive effects of water, nitrogen and phosphorus on the growth, biomass partitioning and water-use efficiency of Bauhinia faberi seedlings. Journal of Arid Environments 74, 1003-1012.
Suding, K.N., Gross, K.L., Houseman, G.R., 2004. Alternative states and positive feedbacks in restoration ecology. Trends in Ecology \& Evolution 19, 46-53.

Tisdall, J.M., Oades, J.M., 1982. Organic matter and water stable aggregates in soils. Journal of Soil Science 33, 141-163.

Väisänen, R.K., Roberts, M.S., Garland, J.L., Frey, S.D., Dawson, L.A., 2005. Physiological and molecular characterization of microbial communities associated with different water-stable aggregate size classes. Soil Biology \& Biochemistry 37, 2007-2016.

Vinton, M.A., Burke, I.C., 1995. Interactions between individual plant species and soil nutrient status in shortgrass steppe. Ecology 76, 1116-1133.

White, D.C., Davis, W.M., Nickels, J.S., King, J.D., Bobbie, R.J., 1979. Determination of the sedimentary microbial biomass by extractable lipid phosphate. Oecologia 40, 51-62.

Whitford, W.G., Sobhy, H.M., 1999. Effects of repeated drought on soil microarthropod communities in the northern Chihuahuan Desert. Biology and Fertility of Soils 28, 117-120.

Wright, A.L., 2009. Phosphorus sequestration in soil aggregates after long-term tillage and cropping. Soil \& Tillage Research 103, 406-411.

Wright, S.F., Upadhyaya, A., 1998. A survey of soils for aggregate stability and glomalin, a glycoprotein produced by hyphae of arbuscular mycorrhizal fungi. Plant and Soil 198, 97-107.

Xu, X.L., Ma, K.M., Fu, B.J., Liu, W., Song, C.J., 2009. Soil and water erosion under different plant species in a semiarid river valley, SW China: the effects of plant morphology. Ecological Research 24, 37-46.

Zuazo, V.H.D., Pleguezuelo, C.R.R., 2008. Soil-erosion and runoff prevention by plant covers. A review. Agronomy for Sustainable Development 28, 65-86. 